\section{Bilynsky Y., Horodetska D., Novytskyi D., Voytsekhovska 0.}

\title{
DEVELOPMENT OF A MATHEMATICAL MODEL OF MEASURING CONTROL DEVICE OF NATURAL GAS HUMIDITY
}

Об’єктом дослідження є вимірювальний контроль вологості природного газу. Існує багато методів i засобів визначення вологості, які використовуються в лабораторних вимірюваннях при нормальних умовах. Однак на практиці потрібно вимірювати вологість в широкому діапазоні зміни тиску та температури, а також при високому та середньому туску в газопроводі. Таке використання потребує розробки сенсорів, які є надійними, стабільними та стійкими до забруднень і високих тисків. Завдяки своїй простій, надійній конструкцї та доволі високій точності вимірювання вологоміри, що базуються на використанні надвисокочастотного методу, набули широкого використання.

На основі проведених досліджень запропоновано засіб вимірювального контролю вологості природного газу на основі надвисокочастотного методу вимірювання вологості, в якому, на відміну від відомих, запропоновано використання біжучої хвилі у хвилеводі. При цьому оцінюються зміни діелектричних властивостей газів при їх взаємодї з хвилями надвисокочастотного діапазону. Проведено дослідження, які показали, що наявність порівняльного каналу дозволило підвищити точність вимірювання, оскільки двоканальна система, на відміну від одноканальної, нівелює нестабільність значення вхідного сигналу, що подається генератором.

Описано принцип роботи засобу вимірювального контролю вологості природного газу, який містить надвисокочастотний генератор, атенюатори, хвилеводні трійники, хвилеводну секцію порівняння, датчик температури та тиску, комутатори порівняльного та вимірювального каналів, вимірювальну кювету, підсилювач, мікропроцесор, індикаторний пристрій.

Розроблено математичну модель засобу вимірювального контролю вологості природного газу, яка враховує значення діелектричної проникності газу вимірювального та опорного каналів та містить коефіцієнти корегування за температурою, використання яких дозволяє підвищити точність вимірювання вологості.

Результати досліджень дають можливість стверджувати про перспективність для практичного застосування вимірювачів вологості природного газу засобів, основаних на надвисокочастотному методі біжучої хвилі.

Ключові слова: надвисокочастотний метод, біжуча хвиля, математична модель, засіб вимірювального контролю вологості природного газу.

Received date: 06.02 .2020

Accepted date: 02.03 .2020

Published date: 30.04 .2020
Copyright (C) 2020, Bilynsky Y., Horodetska O., Novytskyi D., Voytsekhovska O. This is an open access article under the CC BY license (http://creativecommons.org/licenses/by/4.0)

\section{Introduction}

The measurement and control of gas quality parameters is an urgent task of both modern science and its various applications in the national economy. Quality indicators strongly affect the cost of products. Humidity is one of the main parameters in the production, transportation and processing of natural (or associated petroleum) gas [1, 2]. Today, there are a large number of different means of monitoring gas humidity, have a number of disadvantages, namely low accuracy, sensitivity and speed in the entire measurement range $[3,4]$. Many methods are already deprived of the possibility of increasing accuracy. Therefore, the problem arises of applying new approaches to significantly improve the quality parameters meters, aimed at increasing their stability, accuracy, sensitivity. To date, methods using the microwave frequency range have gained widespread use due to their simple, reliable design and fairly high measurement accuracy. So, the object of research is the measuring control of the humidity of natural gas. The aim of research is to increase the accuracy of measuring devices for controlling the humidity of natural gas and developing its mathematical model.

\section{Methods of research}

In [5], the choice of the microwave method for measuring the humidity of natural gas was justified, in which, in contrast to the known methods, the use of a traveling wave in a waveguide is proposed. In this case, changes in the dielectric properties of gases during their interaction with microwave waves are estimated.

The essence of the microwave measurement conversion of natural gas moisture is to absorb the microwave signal, and therefore measure the power of this signal at the output of the waveguide when the humidity of the gas changes by using a traveling wave. The authors proposed a mathematical model of such a microwave measuring conversion of natural gas moisture [5]. The conducted studies of the dependence of the traveling wave power on the absolute 
humidity of water vapor at various values of the microwave signal transmission length in a humid environment, taking into account temperature and pressure. It is found that with increasing absolute humidity of water vapor, the radiation power decreases according to the exponential law.

\section{Research results and discussion}

3.1. Block diagram of a measuring device for controlling natural gas humidity. The conducted studies allowed the development of a measuring device for measuring the natural gas humidity (MDHGH) based on the microwave traveling wave method, the structural diagram of which is shown in Fig. 1. MDHGH is a two-channel and consists of a measuring channel and a comparison channel.

$$
\begin{aligned}
& \text { So, } \\
& P_{m}=P_{c}=\frac{P_{1}}{2}=\frac{1}{2} K_{1} \cdot P_{0} .
\end{aligned}
$$

In addition, when HFEW passes through the waveguide sections of the tee, the power is weakened due to losses at the waveguide transitions associated with the waveguide material, its design features and manufacturing technologies.

3.2. Comparison channel study. In the comparison channel, there is a waveguide section of comparison 4 (comparison cell), which is filled with dry air at a pressure of $1 \mathrm{~atm}$ and a temperature of $20^{\circ} \mathrm{C}$. With these parameters, the comparison cell 4 is hermetically closed. When HFEW passes through the waveguide section of the comparison cuvette, its power is weakened due to the loss on the waveguide section of the comparison cuvette and losses associated with the HFEW passage through the layer of dry air in the comparison cuvette.

In the moisture measurement transformation, based on the use of the traveling waveguide microwave method, the attenuation is measured, which occurs when the HFEW passes through the gas medium depending on its dielectric constant according to $[5,6] K_{4}=e^{-a \cdot L}$, then the HFEW power at the output of the comparison cuvette:

Fig. 1. Structural diagram of a measuring device for measuring the natural gas humidity

MDHGH consists of [5]:

- microwave generator 1 ,

- attenuator 2;

- waveguide tee 3 ;

- waveguide comparison section (comparative cuvette) 4;

- temperature sensor 5,

- switch comparative channel 6,

- pressure sensor measuring waveguide section 7;

- waveguide measuring section (measuring cell) 8;

- temperature sensor 9;

- switch measuring channel 10 ,

- attenuators of the measuring channel and the compa-

rison channel 11 and 13, respectively;

- waveguide tee 12 ;

- diode section 14;

- agreed load 15;

- amplifier 16;

- microprocessor 17;

- analog-to-digital converter (ADC) 18;

- indications 19

MDHGH microwave generator 1, assembled by a PIN diode (a kind of diode in which between the areas of electronic $(n)$ and hole $(p)$ conductivity there is an intrinsic semiconductor ( $i$-region)), tunes to a frequency of $10 \mathrm{GHz}$ with the help of a stabilized correction voltage, which arrives from the microprocessor 17 . Let's denote the power of the high-frequency electromagnetic wave (HFEW), coming from the generator 1 through $P_{0}$. The attenuator 2 attenuates the HFEW through passage by $K_{1}$. The waveguide tee 3 divides the HFEW into two channels: the measuring channel and the comparison channel. HFEW power $P_{1}$ is divided by tee 3 into two channels equally. Let's denote the HFEW power of the measuring channel through $P_{m}$, and the HFEW power of the comparative channel through $P_{c}$.

$$
P_{2}=K_{3} \cdot K_{4} \cdot P_{c}=\frac{1}{2} K_{1} \cdot K_{2} \cdot K_{3} \cdot P_{0} \cdot e^{-a \cdot L},
$$

where $K_{2}$ - the loss coefficient associated with the passage of the waveguide section of the waveguide tee; $K_{3}$ - loss coefficient associated with the HFEW passage through the waveguide section of comparison cell 4 in a vacuum state; $a$ - the attenuation coefficient of dry air; $L$ - the length of the comparison cell.

At the signal of the microprocessor 17, the switch comparative channel 6 opens and the HFEW passes to the input of the attenuator 13. When the HFEW passes through the waveguide section of the switch 6 , its power $P_{2}$ is attenuated by the amount $K_{5}$, and when passing through the waveguide attenuator section 13 , by the amount $K_{6}$. Similarly, let's denote the loss coefficient during the passage of HFEW through the branch of the waveguide tee 12 in $K_{7}$.

The diode in the waveguide section 14 converts the energy of the variable HFEW into direct current $I_{d}$, the value of which is proportional to the power of the signal supplied to the input of the wave diode section 14. Let's denote the conversion coefficient of the diode section $K_{8}$. Then $I_{d}=K_{8} \cdot P_{5}$, the $I_{d}$ current is supplied to the amplifier 16 , at the input of which there is a resistance $R$ - the coordinated load 15. The resistance $R$ turns the $I_{d}$ diode current into a voltage $U$, which is amplified by the amplifier 16 . The current conversion coefficient of the $I_{d}$ diode to voltage $U$ and the conversion coefficient of amplifier 16 will be designated as $K_{9}$ and $K_{10}$, respectively. Then the voltage $U_{c}$ of the comparison channel at the output of the amplifier 16 is equal to:

$$
\begin{aligned}
& U_{c}=K_{9} \cdot K_{10} \cdot I_{d}= \\
& =\frac{1}{2} K_{1} \cdot K_{2} \cdot K_{3} \cdot K_{5} \cdot K_{6} \cdot K_{7} \cdot K_{8} \cdot K_{9} \cdot K_{10} \cdot P_{0} \cdot e^{-a \cdot L} .
\end{aligned}
$$

The $U_{c}$ signal is stored by the microprocessor 17 
3.3. Analysis of the attenuation coefficient $a$. Due to the fact that when HFEW passes through the layer of the gas under investigation, its attenuation a directly depends on the properties of the dielectric constant of the gas, it is necessary to consider the effect of the dielectric constant on the MDHGH operation. The dielectric constant of gases depends on temperature. In [7], a formula is given for adjusting the dielectric constant depending on changes in pressure $p$ and temperature $T$ (in degrees Kelvin scale) of the medium under study. The dielectric constant of dry air is $\varepsilon^{\prime}-1=0.00058$, and $\varepsilon^{\prime \prime}-1=0.000058$ [8]. Attenuation coefficient according to [6]:

$$
a=\frac{2 \pi \cdot K_{d}}{\lambda}=K_{d} \cdot Z,
$$

where $K_{d}$ - the attenuation coefficient of dry air, $K_{d}=f\left(\varepsilon_{d}\right)$ [9]; $\lambda$ - the wavelength that the microwave generator 1 emits, $\lambda=0.03 \mathrm{~m} ; Z=\frac{2 \pi \cdot L}{\lambda}$.

The attenuation coefficient $K_{d}$ of dry air will vary depending on the temperature in reference cell 4:

$$
K_{d t}=K_{d}-K_{t 1} \cdot t,
$$

where $K_{d t}$ - the temperature indicator of the attenuation of dry air (takes into account the deviation of the gas temperature in the comparison cell 4 other than $0{ }^{\circ} \mathrm{C}$ ); $K_{t 1}$ - temperature correction coefficient, for dry air $K_{t 1}=0.00000215$ [4]; $t$ - the dry air temperature in the comparison cell (in degrees Celsius).

Accordingly (3) will take the form:

$$
U_{c}=\frac{1}{2} K_{1} \cdot K_{2} \cdot K_{3} \cdot K_{5} \cdot K_{6} \cdot K_{7} \cdot K_{8} \cdot K_{9} \cdot K_{10} \cdot P_{0} \cdot e^{-\left(K_{c}-K_{t 1} \cdot t\right) \cdot Z} .
$$

3.4. Channel measurement. Let's consider the operation of the MDHGH measuring channel in the case of filling the measuring cell 8 with an air mixture (hereinafter air), which corresponds to the density and permittivity of natural gas, at a pressure of 1 atm [9]. In this case, the dry air temperature in the comparative cell 4 and the temperature of the controlled air in the measuring cell 8 will be equal.

Indoor air mainly consists of the sum of the attenuation of dry air and water vapor. Therefore, the rate of attenuation of controlled air $K_{c}=K_{d}+K_{w}$, where $K_{w}$ - is the rate of attenuation of water vapor equal to:

$$
K_{w}=\sqrt{\frac{1}{2} \cdot \frac{p \cdot 273.15}{760 \cdot T} \cdot \frac{\rho_{v n}}{\rho_{v}} \cdot\left(\sqrt{\left(\varepsilon_{1}^{\prime}-1\right)^{2}+\left(\varepsilon_{1}^{\prime \prime}-1\right)^{2}}-\left(\varepsilon_{1}^{\prime \prime}-1\right)\right)},
$$

where $\rho_{v: n}-$ absolute humidity of water vapor; $\rho_{v}-$ water density.

The dielectric constant of water vapor at a temperature of $20{ }^{\circ} \mathrm{C}$ is $\varepsilon^{\prime}-1=0.0000619$ and $\varepsilon^{\prime \prime}-1=0.0000314$ [4]. It also depends on temperature.

Similarly to (5) and in accordance with [7], let's make adjustments to the dielectric constant of water vapor depending on the temperature of the controlled air inside the measuring cell 8 . The rate of attenuation of dry air, taking into account the temperature adjustment, is known and equal to $K_{c t}$. Therefore, the attenuation rate of con- trolled air, taking into account the temperature correction $K_{t c}$, will be:

$$
K_{t c}=\left(K_{w}-K_{t 2} \cdot t\right)+\left(K_{d}-K_{t 1} \cdot t\right),
$$

where $K_{t 2}$ - temperature correction coefficient, for water vapor $K_{t 2}=0.0000036825 ; K_{t 2}=0.0000036825 ; t-$ a numerical indicator of temperature in a measuring cell (in degrees Celsius).

Then, by analogy with the operation of comparison channel 4, provided that the design and technological parameters of comparison cell 4 and measuring cell 8, waveguide switches 6 and 10 of the attenuators 11 and 13 are equal, let's obtain:

$$
U_{m}=\frac{1}{2} K_{1} \cdot K_{2} \cdot K_{3} \cdot K_{5} \cdot K_{6} \cdot K_{7} \cdot K_{8} \cdot K_{9} \cdot K_{10} \cdot P_{0} \cdot e^{-K_{l k} \cdot Z} .
$$

The signal $U_{m}$ is also remembered by the microprocessor 17 .

3.5. The mathematical model of the device. When the process of memorizing signals $U_{m}$ and $U_{c}$ has passed, the microprocessor 17 performs the operation of dividing these signals. The quotient of the division of signals $U_{m}$ and $U_{c}$, taking into account the conversion coefficient $K_{11}$, is stored by the microprocessor 17 , after which it carries out the logarithm operation. The voltage $U_{m}$ and $U_{c}$ is supplied to the analog input of the microprocessor 17, where the ADC 18 with a conversion factor $K_{12}$ is converted to a digital signal $N$. Then the mathematical model of the device can be written as:

$$
\left\{\begin{array}{l}
\ln \left(\frac{U_{c}}{U_{m}}\right)=\left(\ln K_{11}+\frac{2 \pi \cdot L}{\lambda} \cdot\left(K_{w}-K_{t 2} \cdot t\right)\right) \cdot K_{c a l}, \\
N_{1}=\frac{K_{12} \cdot U_{m}}{U_{o p}} \cdot\left(2^{n_{0}}-1\right), \\
N_{2}=\frac{K_{12} \cdot U_{c}}{U_{o p}} \cdot\left(2^{n_{0}}-1\right),
\end{array}\right.
$$

where $N_{1}$ - the binary value of the code of the $n$-bit ADC, which is digitized the voltage $U_{m}$ of the measuring channel; $\mathrm{N}_{2}$ - binary value of the code of the $n$-bit ADC, digitizes the voltage $U_{m}$ of the comparative channel; $K_{c a l}$ - the conversion coefficient associated with the MDHGH calibration.

MDHGH study is conducted. Natural gas consists of 98-99\% methane $[10,11]$. The dielectric constant of dry methane is $\varepsilon_{m}^{\prime}=1.000953$ at $0{ }^{\circ} \mathrm{C}$ [7]. Dry air is pumped into comparison cuvette 4 . The dielectric constant of dry air is $\varepsilon_{c}^{\prime}=1.0006258$ at $0^{\circ} \mathrm{C}$ [7]. It is established that the relative error $\Delta t$ in the absence of temperature adjustment and when the air temperature changes from $0^{\circ} \mathrm{C}$ to $1^{\circ} \mathrm{C}$ and $-1{ }^{\circ} \mathrm{C}$ leads to an error of $\pm 0.18 \%$. The values of the correction factors and the relative error in their application are also calculated. It is found that a change in gas temperature relative to $0^{\circ} \mathrm{C}$ by $1{ }^{\circ} \mathrm{C}$ and $-1^{\circ} \mathrm{C}$ leads to errors of $0.001 \%$ and $0.000625 \%$, respectively.

\section{Conclusions}

A means of measuring control of the humidity of natural gas is proposed, the principle of which is based on the microwave method for measuring the humidity of natural gas, in which, in contrast to the known methods, the use of a traveling wave in a waveguide is proposed. In this 
case, changes in the dielectric properties of gases during their interaction with microwave waves are estimated.

A mathematical model of the proposed means for measuring the humidity of natural gas has been developed, which takes into account the value of the dielectric constant of the measuring gas and the comparison channel, and contains temperature correction factors, the use of which improves the accuracy of humidity measurement.

A study of the measuring channel, the comparison channel, the attenuation coefficient is made, on the basis of which temperature humidity measurements are corrected. The influence of temperature correction factors on the error in measuring humidity is analyzed. Based on the analysis, it can be concluded that the use of these coefficients makes it possible to compensate with high accuracy the difference in the permittivity of dry methane and dry air. The error in this case when the temperature changes from $0{ }^{\circ} \mathrm{C}$ to $10^{\circ} \mathrm{C}$ does not exceed $0.01 \%$.

\section{References}

1. Korotcenkov, G. (2018) Handbook of Humidity Measurement, Volume 1: Spectroscopic Methods of Humidity Measurement. CRC Press Published, 372. doi: http://doi.org/10.1201/b22369

2. Krause, K. M., van Popta, A., Steele, J. J., Sit, J. C., Brett, M. J. (2007). Microstructured humidity sensors fabricated by glancing angle deposition: characterization and performance evaluation. Device and Process Technologies for Microelectronics, MEMS, Photonics, and Nanotechnology IV. doi: http://doi.org/ $10.1117 / 12.759533$

3. Wang, J., Zhang, H., Cao, Z., Zhang, X., Yin, C., Li, K. et. al. (2016). Humidity sensor base on the $\mathrm{ZnO}$ nanorods and fiber modal interferometer. 8th International Symposium on Advanced Optical Manufacturing and Testing Technologies: Design, Manufacturing, and Testing of Micro- and Nano-Optical Devices and Systems; and Smart Structures and Materials. doi: http://doi.org/ $10.1117 / 12.2244482$

4. Luo, S., Yang, L., Liu, J. (2020). Statistical characteristics analysis of global specific humidity vertical profile. 2019 International Conference on Optical Instruments and Technology: Optoelectronic Measurement Technology and Systems. doi: http:// doi.org/10.1117/12.2544132
5. Bilynsky, Y. Y., Horodetska, O. S., Novytskyi, D. V. (2019). Development of Mathematical Model of Two-channel Microwave Measuring Converter of the Humidity of Natural Gas. Visnyk of Vinnytsia Politechnical Institute, 145 (4), 19-24. doi: http:// doi.org/10.31649/1997-9266-2019-145-4-19-24

6. Bilenko, D. I. (1999) Kompleksnaia dielektricheskaia pronitsaemost. Plazmennyi rezonans svobodnykh nositelei zariada v poluprovodnikakh. Izd-vo Sarat. uni-ta, 44.

7. Brandt, A. A. (1963). Issledovanie dielektrikov na sverkhoysokikh chastotakh. Mosocw: Fizmatgiz, 404.

8. Iakovlev, K. P.; Iakovlev, K. P. (Ed.) (1960). Kratkii fizikotekhnicheskii spravochnik. Moscow: Fizmatgiz, 446.

9. Bilynsky, Y. Y., Horodetska, O. S., Novytskyi, D. V. (2019). Development of a mathematical model of the waveguide microwave measuring conversion the humidity of natural gas. Visnyk KhNU. Tekhnichni nauky, 3, 131-137.

10. Zyska, T., Bilinsky, Y., Saldan, Y., Ogorodnik, K., Lazarev, A., Horodetska, O., Mussabekova, A. (2018). New ultrasound approaches to measuring material parameters. Photonics Applications in Astronomy, Communications, Industry, and High-Energy Physics Experiments 2018. doi: http://doi.org/10.1117/12.2501637

11. Chen, Z., Lu, C. (2005). Humidity Sensors: A Review of Materials and Mechanisms. Sensor Letters, 3 (4), 274-295. doi: http://doi.org/10.1166/sl.2005.045

Bilynsky Yosyp, Doctor of Technical Sciences, Professor, Head of Department of Electronics and Nanosystems, Vinnytsia National Technical University, Ukraine, e-mail: yosyp.bilynsky@gmail.com, ORCID: http://orcid.org/0000-0002-9659-7221

Horodetska Oksana, PhD, Assistant Professor, Department of Telecommunication Systems and Television, Vinnytsia National Technical University,Ukraine, e-mail: horodecka.os@gmail.com,ORCID: http:// orcid.org/0000-0001-6929-1123

Novytskyi Dmytro, Postgraduate Student, Department of Electronics and Nanosystems, Vinnytsia National Technical University, Ukraine, e-mail: yosyp.bilynsky@gmail.com, ORCID: http://orcid.org/ 0000-0001-6033-406X

Voytsekhovska Olena, PhD, Assistant Professor, Department of Computer Engineering, Vinnytsia National Technical University, Ukraine, e-mail:vojcexovska.o.v@vntu.edu.ua, ORCID: http://orcid.org/ 0000-0001-8755-1574 